\title{
Zonguldak Bülent Ecevit Üniversitesi Tıp Fakültesi Öğrencilerinde Çevrimiçi Oyun Bağımlılığının Stres, Anksiyete, Depresyon ve Bașarı Üzerine Etkisi
}

\author{
Effects of Online Game Addiction on Stress, Anxiety, Depression and \\ Success at Students of Zonguldak Bulent Ecevit University School of \\ Medicine
}

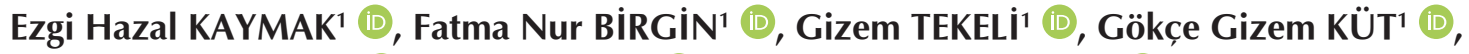 \\ Hale Hatice AKGÜN¹ (D), Hasan BAKLA ${ }^{1}$ (D), Hatice Sümeyye ÖNCEL ${ }^{1}$ (D), Mustafa Çağatay BÜYÜKUYSAL ${ }^{2}$ \\ ${ }^{1}$ Zonguldak Bülent Ecevit Üniversitesi, Tıp Fakültesi Öğrencisi, Zonguldak, Türkiye \\ ${ }^{2}$ Zonguldak Bülent Ecevit Üniversitesi, Tıp Fakültesi, Biyoistatistik Anabilim Dalı, Zonguldak, Türkiye
}

ORCID ID: Ezgi Hazal Kaymak 0000-0002-7946-1023, Fatma Nur Birgin 0000-0002-0013-5920, Gizem Tekeli 0000-0002-5729-3102, Gökçe Gizem KÜT 0000-0002-0654-1102, Hale Hatice Akgün 0000-0001-6163454X, Hasan Bakla 0000-0003-2186-9525,

Hatice Sümeyye Öncel 0000-0002-4235-7898, Mustafa Çağatay Büyükuysal 0000-0001-9810-5633

Bu makaleye yapılacak atıf: Kaymak EH, Birgin FN, Tekeli G, Küt GG, Akgün HH, Bakla H, Öncel HS, Büyükuysal MÇ. Zonguldak Bülent Ecevit Üniversitesi Tıp Fakültesi Öğrencilerinde Çevrimiçi Oyun Bağımlılığının Stres, Anksiyete, Depresyon ve Bașarı Üzerine Etkisi. Med J West Black Sea. 2021;5(1):33-43.

Sorumlu Yazar

Mustafa Çağatay Büyükuysal

E-posta

cbuyukuysal@gmail.com

Geliș Tarihi

02.12.2020

Revizyon Tarihi

28.01.2021

Kabul Tarihi

29.01.2021
Öz

Amaç: Oyun bağımlılı̆ı, bilgisayar ve video oyunlarının sosyal ve/veya duygusal problemler doğuran aşırı ve problemli kullanımı olarak tanımlanmaktadır. Bağımlılar bilgisayar ve video oyunları için daha fazla zaman yaratmak adına derslerini, uykularını, beslenmelerini, hobilerini ve sosyal hayatlarını inmal etmektedir. ICD-11 listesinde de giren bu hastalık, teknolojinin de ilerlemesiyle çağın en yaygın hastalıklarından biri hâline gelmektedir. Bu çalıșmada çevrimiçi oyun oynamanın tıp fakültesi öğrencilerinde stres, anksiyete, depresyon ve başarı puanlarının nasıl etkilendiği incelenmiştir.

Gereç ve Yöntemler: Zonguldak Bülent Ecevit Üniversitesi Tıp Fakültesi Dönem 1, 2 ve 3 öğrencilerinden toplam 234 kişiye depresyon anksiyete stres ölçeği, internet bağımlılığı ölçeği ve oyun motivasyon ölçekleri uygulanmıştır. Ölçek puanlarının normal dağılıma uygunluğu Shapiro Wilk testi ile incelenmiştir. Bağımsız grup karşılaştırmalarında Mann Whitney U ve Kruskal Wallis testleri kullanılmıştır. Sürekli değişkenler arası ilişkiler Spearman korelasyon katsayıları ile incelenmiştir. Öğrencilerin demografik özellikleri ve günlük alışkanlıklarının; ölçeklerden elde edilen puanlarla ve başarılarıyla ilişkileri değerlendirilmiştir.

Bulgular: Erkek ve kadın öğrenciler arasında anksiyete, stres ve depresyon ve internet bağımlılı̆ı bakımından istatistiksel olarak anlamlı farklılık yok iken oyun bağımlıı̆̆ı erkeklerde daha fazla bulunmuştur. Oyun bağımlığı ile beraber oyun bağımlıığını alt boyutları içsel motivasyon, bütünleşme, kimlik katma, içe yansıtma, dışsal düzenleme ve motivasyonsuzluk da erkeklerde kadınlara göre anlamlı derecede yüksek çıkmıştır.

Sonuç: Çalışma sonuçlarına göre çevrimiçi oyun bağımlılığının kadın öğrencilere oranla erkeklerde daha fazla olduğu ve söz konusu bağımlılığın başarıyı olumsuz etkilediği görülmüştür. Bununla beraber hem kadın hem erkek öğrencilerde oyun bağımlılığı artıkça beraberinde öğrencilerin depresyon, stres ve anksiyete puanlarının da arttığı görülmektedir.

Anahtar Sözcükler: Çevrimiçi oyun bağımlılığı, Stres, Anksiyete, Depresyon, Başarı durumu 


\begin{abstract}
Aim: Game addiction is defined as the excessive and problematic use of computer and video games that cause social and emotional problems. Addicts neglect their lessons, sleep, nutrition, hobbies and social lives to create more tiem for computer and video games. This disease, which is also on the ICD-11 list, is becoming one of the most common diseases of the age with the advancement of technology. The aim of this study is to investigate the effects of online play on stress, anxiety, depression and achievement scores in medical students.

Materials and Methods: Depression Anxiety Stress Scale, Internet Addiction Scale and Game Motivation Scales were applied to 234 students of Zonguldak Bulent Ecevit University Faculty of Medicine, $1^{\text {st }}, 2^{\text {nd }}$ and $3^{\text {rd }}$ grade. Shapiro Wilk test used for test of normality. Mann Whitney U and Kruskal Wallis tests used for independent group comparisons. Spearman correlation coefficient used to evaluate the relationship between continious variables. Relationship between demographic characteristics and daily habits with term success of the students and scores from each scale are evaluated.
\end{abstract}

Results: While there was no statistically significant difference between male and female students in terms of anxiety, stress and depression, and internet addiction, game addiction was higher in male students. Along with the game addiction, the sub-factors of game addiction as motivation, integration, identification, external regulation and lack of motivation are also found statistically high in males than in female students.

Conclusion: According to the results of the study, it was seen that online game addiction was higher in males than in female students and this addiction had a negative effect on success. However, as the game addiction increases in both male and female students, it is seen that the depression, stress and anxiety scores of the students increase.

Keywords: Online game addictive, Stress, Anxiety, Depression, Success

\section{Giriș}

Bilişim teknolojisinde son 30 yılda yaşanan hızlı gelişmeler bilgisayar, cep telefonu ve internet kullanımında ciddi bir artışa sebep olmuş ve günlük hayatın olmazsa olmazları arasına girmiştir. Teknolojideki gelişimin her alanda hayatımıza girmesi her ne kadar kullanıcılara pratiklik ve zaman tasarrufu sağlasa da, doğru kullanılmaması bir takım davranışların değişimine, yeni alışkanlıklar edinilmesine ve beraberinde yeni bağımlılıkların ortaya çıkmasına sebep olmuştur. Günlük internet kullanım süresinin gün geçtikçe artması, kişilerin sosyal ilişkilerine ayırdıkları zamanı kısaltarak sosyal yaşamlarını olumsuz etkilemeye başlamıştır. Bunun neticesinde insanın en doğal gereksinimlerinden olan sosyalleşme intiyacı internet, sosyal medya veya online oyunlar üzerinden karşılanmaya başlanmıştır. Bu sosyalleşme intiyacı her yaş grubunda farklı davranışlar göstermekle beraber genç kesimde daha çok online oyun ile karşılanmıştır.

Oyun tarihinin neredeyse insanlık tarihi kadar eski olduğu bilinmektedir. Günümüzde bilinen çoğu oyunun ilk çağlarda da bilindiği arkeologlar tarafından yapılan çalışmalarla bilinmektedir. İlk çağlardan günümüze dek pek çok unsur oyunlara ilham kaynağı olmuştur. Bu çağlardaki oyunlar daha çok taş, sopa, kemik gibi nesnelerle birden çok kişi ile oynanan hem eğitici hem de sosyalliği artıran oyunlar olmuştur. Modern çağda ise bilinen geleneksel oyunlar yavaş yavaş yerini, teknolojinin de gelişmesiyle, dijital oyunlara bırakmıştır. Dijital oyunlar ise, geleneksel oyunların aksine daha bireysel oynanmasından dolayı sosyalliği azaltan, kişiyi yalnızlığa iten ve beraberinde bağımlılığı artırır niteliktedirler.

Bağımlılık; bir maddenin veya bir davranışın ruhsal, fiziksel ya da sosyal sorunlara yol açmasına rağmen, alımına devam edilmesi, bırakma isteğine karşılık bırakılamaması ve maddeyi alma veya davranışı sürdürme isteğinin durdurulamamasıdır. Bağımlılık kronik bir beyin hastalığı olarak görülmektedir (1). Oyun bağımlılığı literatürde, oyun oynama süresini kontrol edememe, sosyal çevreye karşı ilgi kaybı, yarattığı negatif sonuçlara rağmen devam etme ve oynamadığı zamanlarda psikolojik- yoksunluk hissetme gibi belirtilerle görülen bir davranış bozukluğu olarak tanımlanmaktadır (2). Bağımlılar oyun için daha fazla zaman yaratmak adına derslerini, uykularını, beslenmelerini, hobilerini ve sosyal hayatlarını inmal etmektedir. Online oyun başında daha fazla zaman geçirdikçe; sosyal hayattan uzaklaşan, uyku düzeni ve beslenmesi bozulan, derslerinde başarısız olmaya başlayan kişi, yaşadığı tatminsizliği online oyun oynayarak kapatmaya çalışmakta ve oluşan bu kısır döngüden çıkmakta zorlanmaktadır. Bağımlı kişi, oyun oynamadığı dönemde düşen dopamin seviyesiyle birlikte yoksunluk sendromu yaşamakta ve sadece oyun oynayarak dopamin seviyesini yükselterek bu sendromdan çıkabilmektedir.

Bu çalışmada üniversite öğrencilerinde, çevrimiçi oyun oynamanın; stres, anksiyete, depresyon, başarı ve sosyal yaşam gibi fizyolojik ve psikolojik değişkenlere etkisinin gözlemlenmesi amaçlanmıştır.

\section{GEREÇ ve YÖNTEMLER}

Zonguldak Bülent Ecevit Üniversitesi Tıp Fakültesi Dönem 1, Dönem 2 ve Dönem 3 öğrencileri üzerinde yapılan analitik araştırmada toplam 559 öğrenciye ulaşılması hedeflenmiş olup 234 kişi ile çalışma tamamlanmıştır. Öğrencilere depresyon anksiyete stres ölçeği, internet bağımlılığı ölçeği ve oyun motivasyon ölçekleri uygulanmıştır.

\section{Depresyon Anksiyete Stres Ölçeği (DASS-21)}

Ölçeğin Lovibond (1995) tarafından geliştirilen Depresyon Anksiyete Stres Ölçeği (DASS) 42 maddeden oluşmaktadır. "0 - bana hiç uygun değil”, "1 - bana biraz uygun", "2 - bana genellikle uygun”, "3 - bana tamamen uygun" şekline 4'lü likert tipi bir derecelendirmeye sahiptir. Brown ve ark. (1997) 
bu ölçeğin daha kısa formlarının da aynı ölçümü gerçekleştirebilecek geçerliliğe sahip olduğunu göstermişlerdir. Bu çalışmada depresyon anksiyete ölçeğinin 21 soruluk Türkçe güvenirliği geçerliği yapılmış kısa formu (DASS-21) kullanılmıştır $(3,4)$.

\section{Internet Bağımlıı̆ğı Ölçeği}

Hahn ve Jerusalem (2001) tarafından tasarlanan internet bağımlılık ölçeği Cengiz Sahin ve Özgen Korkmaz tarafından Türkçeye uyarlanmıştır. Çalışma 19 sorudan oluşmakta olup, 1 "Katılmıyorum", 2 "Kararsızım", 3 "Katılıyorum" şeklinde 3'lü likert tipi bir derecelendirmeye sahiptir. Kişi ne kadar yüksek puan alırsa internet bağımlılığının o kadar yüksek olduğu sonucuna varılır $(5,6)$.

\section{Oyun Motivasyonu Ölçeği}

Lafrenière, Verner-Filion ve Vallerand tarafından (2012) özbelirleme kuramı çerçevesinde hiyerarşik motivasyon kuramına göre geliştirilmiş bir ölçektir.

Ölçeğin toplam madde sayısı 18 olup ölçek;

1: Hiç Katılmıyorum

7: Tamamen Katılıyorum şeklinde 7’li likert tipi bir derecelendirmeye sahiptir.

Ölçeğin alt ölçekleri olan içsel motivasyon, bütünleşme, kimliğe katma, içe yansıtma, dışsal düzenleme, motivasyonsuzluk alt boyutlarının her biri 3'er maddeden oluşmaktadır (7).

Çalışmaya katılan öğrencilerden yazılı onam formları alınmış ve çalışma için Zonguldak Bülent Ecevit Üniversitesi Insan Araştırmaları Etik Kurulu'ndan 29.07.2020 tarihinde 853 protokol numarası ile izin alınmıştır.

Çalışmanın istatistiksel analizleri Jamovi 1.2.27 ve Excel 2013 paket programlarında yapılmıştır. Çalışmada yer alan nitel değişkenlere ait tanımlayıcı istatistikler frekans ve yüzde ile, sürekli değişkenler ortalama, standart sapma, medyan, minimum ve maksimum değerleriyle verilmiştir. Sürekli değişkenlerin normal dağılıma uygunluğu Shapiro Wilk testi ile incelenmiştir. Sürekli değişkenlerin 2 grup karşılaştırmalarında Mann Whitney $U$ testi; 3 ve daha fazla grup karşı- laştırmalarında Kruskal Wallis testileri kullanılmıştır. Sürekli değişkenler arası ilişkiler Spearman korelasyon katsayıları ile incelenmiştir. Çalışmadaki tüm istatistiksel karşılaştırmalarda p değeri 0,05 'in altındaki sonuçlar istatistiksel olarak anlamlı kabul edilmiştir.

\section{BULGULAR}

Çalışmaya ait demografik özellikler Tablo 1'de gösterilmiştir. Çalışmada yer alan 234 öğrencinin 144'ü $(\% 61,5)$ kadın, 90’ $(\% 38,5)$ erkektir. Bununla beraber öğrencilerin 88'i $(\% 37,6)$ dönem-1, 43’ü $(\% 18,4)$ dönem-2 ve 103'ü $(\% 44)$ dönem-3 öğrencisidir.

Tablo 1: Demografik Özellikler

\begin{tabular}{|c|c|c|c|}
\hline & & $\mathbf{n}$ & $\%$ \\
\hline \multirow{2}{*}{ Cinsiyet } & Kadın & 144 & 61,5 \\
\hline & Erkek & 90 & 38,5 \\
\hline \multirow{3}{*}{ Dönem } & Dönem-1 & 88 & 37,6 \\
\hline & Dönem-2 & 43 & 18,4 \\
\hline & Dönem-3 & 103 & 44,0 \\
\hline \multirow{3}{*}{ İkâmet } & Ailesiyle & 88 & 37,6 \\
\hline & Yurt / Apartta Tek & 43 & 18,4 \\
\hline & Yurt / Apartta Arkadaşlarıyla & 103 & 44,0 \\
\hline \multirow{5}{*}{ Gelir } & $0-500$ も & 34 & 14,6 \\
\hline & 501-1000も & 81 & 34,8 \\
\hline & 1001-1500も & 56 & 24,0 \\
\hline & 1501-2000も & 29 & 12,4 \\
\hline & 2001 も ve üzeri & 33 & 12,4 \\
\hline \multirow{4}{*}{$\begin{array}{l}\text { Aylık } \\
\text { oyunlara } \\
\text { ayrılan pay }\end{array}$} & $\% 0-10$ & 217 & 93,1 \\
\hline & $\% 11-20$ & 7 & 3,0 \\
\hline & $\% 21-40$ & 5 & 2,1 \\
\hline & $\% 41-60$ & 4 & 1,7 \\
\hline \multirow{5}{*}{$\begin{array}{l}\text { Aylık } \\
\text { Harcama }\end{array}$} & $0-500$ も & 50 & 21,4 \\
\hline & 501-1000も & 83 & 35,5 \\
\hline & 1001-1500も & 63 & 26,9 \\
\hline & 1501-2000も & 26 & 11,1 \\
\hline & 2001 も ve üzeri & 12 & 5,1 \\
\hline
\end{tabular}

Tablo 2: Cinsiyete göre anksiyete, stres, depresyon ve internet bağımlılığı karşılaştırması

\begin{tabular}{lccc}
\hline & Erkek & Kadın & p \\
\hline \multirow{2}{*}{ Anksiyete } & $0,72 \pm 0,62$ & $0,72 \pm 0,62$ & \multirow{2}{*}{0,971} \\
& $0,6(0-2,4)$ & $0,7(0-3,0)$ & $0,89 \pm 0,75$ \\
\multirow{2}{*}{ Stres } & $0,88 \pm 0,79$ & $0,7(0-3,0)$ & 0,828 \\
& $0,7(0-3,0)$ & $0,72 \pm 0,72$ & 0,903 \\
\multirow{2}{*}{ Depresyon } & $0,78 \pm 0,86$ & $0,6(0-3,0)$ & \multirow{2}{*}{0,331} \\
\hline \multirow{2}{*}{ İnt. Bağ. Puanı } & $0,4(0-3,0)$ & $30,6 \pm 8,5$ & $29,0(19,0-56,0)$ \\
\hline
\end{tabular}

\#Mann Whitney U testi 
Tablo 2 incelendiğinde, erkeklerle kadınlar arasında anksiyete, stres, depresyon ve internet bağımlılığı bakımından istatistiksel olarak anlamlı farklılık saptanmamıştır ( $p$ değerleri sırasıyla 0,$971 ; 0,828 ; 0,903$ ve 0,331 ).

Tablo 3'de oyun motivasyon ölçeği ile elde edilen oyun bağımlılık puanı ve buna ait alt boyutların cinsiyete göre karşılaştırma sonuçları yer almaktadır. Buna göre oyun bağımıılığı ölçeği ve tüm alt boyutları kadın ve erkek öğrenciler arasında istatistiksel olarak anlamlı farklılık göstermektedir ( $p<0,001)$. Bakıldığında oyun bağımlılığı ölçeğinin tüm alt boyutlarında erkekler daha yüksek puanlar almışlardır. Başka bir ifade ile erkek öğrencilerin oyun bağımlılığına yatkınııkları kadın öğrencilerden daha fazladır.

Stres, anksiyete, depresyon ve internet bağımlılığının dönemler arası karşılaştırma sonuçları incelendiğinde dönemler arasında sadece anksiyete skoru bakımından istatistiksel olarak anlamlı farklılık vardır $(p=0,019)$. Anksiyetedeki farklılık incelendiğinde, dönem-1 ve dönem-2 öğrencilerinin anksiyetelerin benzer olduğu, dönem-3 öğrencilerinin anksiyete seviyesinin dönem-1 ve 2'deki öğrencilerden daha

Tablo 3: Oyun bağımlıığı alt boyutlarının cinsiyete göre karşılaştırılması

\begin{tabular}{lccc}
\hline & Erkek & Kadın & $\mathbf{p}$ \\
\hline \multirow{2}{*}{ İçsel Motivasyon } & $3,16 \pm 1,60$ & $2,29 \pm 1,45$ & 0 \\
& $3,00(1,0-7,0)$ & $2,00(1,0-7,0)$ & 0,001 \\
\hline \multirow{2}{*}{ Bütünleşme } & $2,53 \pm 1,54$ & $1,67 \pm 1,17$ & 0,001 \\
& $2,00(1,0-7,0)$ & $1,00(1,0-7,0)$ & \\
\hline \multirow{2}{*}{ Kimlik Katma } & $2,63 \pm 1,74$ & $1,91 \pm 1,33$ & \multirow{2}{*}{0,001} \\
& $2,00(1,0-7,0)$ & $1,00(1,0-7,0)$ & \\
\hline \multirow{2}{*}{ İçe Yansıtma } & $2,11 \pm 1,35$ & $1,53 \pm 1,05$ & 0,001 \\
& $1,7(1,0-7,0)$ & $1,00(1,0-7,0)$ & \\
\hline \multirow{2}{*}{ Dışsal Düzenleme } & $2,68 \pm 1,72$ & $1,79 \pm 1,33$ & \multirow{2}{*}{0,001} \\
& $2,3(1,0-7,0)$ & $1,00(1,0-7,0)$ & \\
\hline \multirow{2}{*}{ Motivasyonsuzluk } & $2,75 \pm 1,75$ & $1,96 \pm 1,32$ & \multirow{2}{*}{0,001} \\
& $2,3(1,0-7,0)$ & $1,3(1,0-6,3)$ & \\
\hline
\end{tabular}

\#Mann Whitney U testi düşük olduğu görüşmüştür. Bununla beraber dönemler arasında stres, depresyon ve internet bağımlılığı puanları bakımından anlamlı farklılık yoktur ( $p>0,05)$ (Tablo 4).

Tablo 5'de oyun motivasyon ölçeği ile elde edilen oyun bağımlılık puanı ve buna ait alt boyutların dönemlere göre karşılaştırma sonuçları yer almaktadır. Buna göre oyun bağımlılığı ölçeği ve tüm alt boyutları kadın ve erkek öğrenciler arasında anlamlı farklılık göstermemektedir ( $p>0,05)$.

Kişilerin yaşadıkları yere göre anksiyete, stres, depresyon ve internet bağımlılık puanları anlamlı derecede farklılık göstermemektedir ( $p$ değerleri sırasıyla 0,857; 0,489; 0,182 ve 0,638$)$. (Tablo 6).

Tablo 7'de oyun motivasyon ölçeği ile elde edilen oyun bağımlılık ölçeği ait alt boyutların yaşadıkları yere göre karşılaştırma sonuçları yer almaktadır. Buna göre oyun bağımıılığı ölçeğinin tüm alt boyutları kadın ve erkek öğrenciler arasında istatistiksel olarak anlamlı farklılık göstermemektedir ( $p>0,05)$.

Hobi varlığının anksiyete, stres ve internet bağımlılığına istatistiksel olarak anlamlı bir etkisinin olmadığı görülmüştür. ( $p$ değerleri sırasıyla 0,$267 ; 0,441$ ve 0,161 ). Ancak hobisi olan öğrencilerin depresyon puanlarının anlamlı derecede daha düşük olduğu saptanmıştır $(p=0,023)$. (Tablo 8).

İnternet bağımlıığının anksiyete, stres, depresyon ve öğrencinin başarısına etkisi incelendiğinde istatistiksel olarak anlamlı derecede etkilediği Şekil 1, 2, 3 ve 4'te gösterilmiştir.

Şekil 1 - 4 incelendiğinde; internet bağımlılığı arttıkça öğrencilerde anksiyete, stres ve depresyon da artış göstermektedir. İnternet bağımlılığının anksiyete etkisi \%21,9 iken, strese etkisi \%13,1 ve depresyona etkisi \%14,8 bulunmuştur. Bu sonuçlara paralel bir şekilde internet bağımlılığı ile başarı puanı arasında zayıf da olsa anlamlı negatif ilişki bulunmuştur ( $r=-0,162 ; p=0,001)$.

Online oyun bağımlılığının anksiyete, stres, depresyona ve öğrencinin başarısına etkisi incelendiğinde istatistiksel olarak anlamlı derecede etkilediği Şekil 5 - 8'de gösterilmiştir.

Tablo 4: Dönemlere göre anksiyete, stres, depresyon ve internet bağımlılığı karşılaştırması

\begin{tabular}{lcccc}
\hline & Dönem 1 & Dönem 2 & Dönem 3 & p \\
\hline \multirow{2}{*}{ Anksiyete } & $0,83 \pm 0,69$ & $0,78 \pm 0,58$ & $0,58 \pm 0,54$ & 0,019 \\
& $0,7(0-3,0)$ & $0,7(0-2,43)$ & $0,4(0-2,29)$ & $0,82 \pm 0,75$ \\
\multirow{2}{*}{ Stres } & $0,94 \pm 0,79$ & $0,93 \pm 0,76$ & $0,6(0-3,0)$ & 0,441 \\
\hline \multirow{2}{*}{ Depresyon } & $0,7(0-3,0)$ & $0,9(0-2,43$ & $0,68 \pm 0,78$ & 0,210 \\
& $0,80 \pm 0,77$ & $0,78 \pm 0,77$ & $0,3(0-3,0)$ & $29,8 \pm 7,9$ \\
\multirow{2}{*}{ İnt. Bağ. Puanı } & $0,6(0-3,0)$ & $0,7(0-3,0)$ & $28,0(19,0-51,0)$ & 0,634 \\
\hline
\end{tabular}

\# Kruskal Wallis testi 
Tablo 5: Oyun bağımlılığı alt boyutlarının dönemlere göre karşılaştırılması

\begin{tabular}{|c|c|c|c|c|}
\hline & Dönem 1 & Dönem 2 & Dönem 3 & $\mathbf{p}$ \\
\hline \multirow{2}{*}{ İçsel Motivasyon } & $2,74 \pm 1,56$ & $2,25 \pm 1,35$ & $2,70 \pm 1,64$ & \multirow{2}{*}{0,176} \\
\hline & $2,3(1,0-7,0)$ & $2,0(1,0-5,3)$ & $2,3(1,0-7,0)$ & \\
\hline \multirow{2}{*}{ Bütünleşme } & $2,05 \pm 1,42$ & $2,02 \pm 1,32$ & $1,96 \pm 1 \mathrm{i} 41$ & \multirow{2}{*}{0,885} \\
\hline & $1,5(1,0-7,0)$ & $1,3(1,0-6,3)$ & $1,3(1,0-7,0)$ & \\
\hline \multirow{2}{*}{ Kimlik Katma } & $2,31 \pm 1,42$ & $2,33 \pm 1,62$ & $2,03 \pm 1,61$ & \multirow{2}{*}{0,126} \\
\hline & $1,8(1,0-6,0)$ & $1,3(1,0-7,0)$ & $1,0(1,0-7,0)$ & \\
\hline \multirow{2}{*}{ İçe Yansıtma } & $1,95 \pm 1,41$ & $1,67 \pm 0,96$ & $1,63 \pm 1,10$ & \multirow{2}{*}{0,372} \\
\hline & $1,3(1,0-7,0)$ & $1,0(1,0-5,0)$ & $1,0(1,0-5,0)$ & \\
\hline \multirow{2}{*}{ Dışsal Düzenleme } & $2,40 \pm 1,67$ & $1,86 \pm 1,21$ & $2,04 \pm 1,56$ & \multirow{2}{*}{0,116} \\
\hline & $1,7(1,0-6,3)$ & $1,0(1,0-5,7)$ & $1,0(1,0-7,0)$ & \\
\hline \multirow{2}{*}{ Motivasyonsuzluk } & $2,26 \pm 1,54$ & $2,23 \pm 1,60$ & $2,28 \pm 1,60$ & \multirow{2}{*}{0,865} \\
\hline & $1,7(1,0-6,3)$ & $1,3(1,0-7,0)$ & $1,7(1,0-7,0)$ & \\
\hline
\end{tabular}

\#Kruskal Wallis testi

Tablo 6: Yaşadığı yere göre anksiyete, stres, depresyon ve internet bağımlılığı karşılaştırması

\begin{tabular}{lcccc}
\hline & Ailesiyle & Yurt / Apart Tek & Yurt / Apart Arkadaşla & $\mathbf{p}$ \\
\hline \multirow{2}{*}{ Anksiyete } & $0,71 \pm 0,58$ & $0,74 \pm 0,62$ & $0,70 \pm 0,63$ & 0,857 \\
& $0,6(0-2,4)$ & $0,6(0-2,9)$ & $0,57(0-3)$ & 0,489 \\
\multirow{2}{*}{ Stres } & $0,97 \pm 0,76$ & $0,93 \pm 0,79$ & $0,83 \pm 0,76$ & $0,57(0-3)$ \\
\hline \multirow{2}{*}{ Depresyon } & $0,9(0-3)$ & $0,8(0-3)$ & $0,65 \pm 0,71$ & 0,182 \\
& $0,95 \pm 0,85$ & $0,78 \pm 0,82$ & $0,42(0-3)$ & $30,0 \pm 8,9$ \\
\multirow{2}{*}{ İnt. Bağ. Puanı } & $0,9(0-3)$ & $0,5(0-3)$ & $28(19-57)$ & 0,638 \\
\hline
\end{tabular}

\#Kruskal Wallis testi

Tablo 7: Oyun bağımlılığı alt boyutlarının ikâmet yerine göre karşılaştırılması

\begin{tabular}{|c|c|c|c|c|}
\hline & Ailesiyle & Yurt / Apart Tek & Yurt / Apart Arkadaşlarıyla & $\mathbf{p}$ \\
\hline \multirow{2}{*}{ İçsel Motivasyon } & $3,00 \pm 1,56$ & $2,67 \pm 1,71$ & $2,49 \pm 1,43$ & \multirow{2}{*}{0,205} \\
\hline & $2,8(1-6,3)$ & $2,2(1-7)$ & $2,3(1-7)$ & \\
\hline \multirow{2}{*}{ Bütünleşme } & $2,10 \pm 1,26$ & $2,22 \pm 1,64$ & $1,82 \pm 1,19$ & \multirow{2}{*}{0,242} \\
\hline & $1,7(1-5,3)$ & $1,5(1-7)$ & $1,3(1-7)$ & \\
\hline \multirow{2}{*}{ Kimlik Katma } & $2,27 \pm 1,58$ & $2,29 \pm 1,78$ & $2,09 \pm 1,33$ & \multirow{2}{*}{0,789} \\
\hline & $1,7(1-7)$ & $1,5(1-7)$ & $1,5(1-6)$ & \\
\hline \multirow{2}{*}{ İçe Yansıtma } & $1,94 \pm 1,23$ & $1,81 \pm 1,27$ & $1,67 \pm 1,16$ & \multirow{2}{*}{0,417} \\
\hline & $1,3(1-5,3)$ & $1(1-7)$ & $1(1-7)$ & \\
\hline \multirow{2}{*}{ Dışsal Düzenleme } & $2,56 \pm 1,92$ & $2,18 \pm 1,57$ & $1,98 \pm 1,40$ & \multirow{2}{*}{0,470} \\
\hline & $1,5(1-6,3)$ & $1,3(1-7)$ & $1,3(1-6,3)$ & \\
\hline \multirow{2}{*}{ Motivasyonsuzluk } & $2,29 \pm 1,44$ & $2,24 \pm 1,63$ & $2,28 \pm 1,52$ & \multirow{2}{*}{0,767} \\
\hline & $1,7(1-6)$ & $1,7(1-7)$ & $1,7(1-6,3)$ & \\
\hline
\end{tabular}

\#Kruskal Wallis testi

Buna göre, online oyun bağımlılığı arttıkça öğrencilerde az da olsa anksiyete, stres ve depresyonda artış göstermektedir ( $r$ değerleri sırasıyla 0,$247 ; 0,166$ ve 0,$196 ; p<0,05$ ).
Internet bağımlılığı gibi online oyun bağımlılığı ile başarı puanı arasında zayıf da olsa anlamlı negatif ilişki bulunmuştur $(r=-0,170 ; p=0,016)$. 
Kaymak EH ve ark.

Tablo 8: Hobiye göre anksiyete, stres, depresyon ve internet bağımlılığı karşılaştırması

\begin{tabular}{lccc}
\hline & Hobi var & Hobi yok & $\mathbf{p}$ \\
\hline \multirow{2}{*}{ Anksiyete } & $0,67 \pm 0,57$ & $0,83 \pm 0,73$ & \multirow{2}{*}{0,267} \\
& $0,6(0-3)$ & $0,6(0-2,9)$ & \\
\hline \multirow{2}{*}{ Stres } & $0,86 \pm 0,76$ & $0,95 \pm 0,82$ & 0,441 \\
& $0,7(0-3)$ & $0,7(0-3)$ & \\
\hline \multirow{2}{*}{ Depresyon } & $0,66 \pm 0,72$ & $0,97 \pm 0,89$ & 0 \\
& $0,4(0-3)$ & $0,9(0-3)$ & \\
\hline \multirow{2}{*}{ Int. Bağ. Puanı } & $29,7 \pm 8,4$ & $31,8 \pm 9,9$ & \multirow{2}{*}{0,161} \\
& $28(19-55)$ & $30(19-57)$ & \\
\hline
\end{tabular}

\#Mann Whitney U testi
Tablo 9: Oyun bağımlılığı alt boyutlarının hobi varlığına göre karşılaştırılması

\begin{tabular}{|c|c|c|c|}
\hline & Hobi var & Hobi yok & $p$ \\
\hline İçsel Motivasyon & $\begin{array}{c}2,68 \pm 1,58 \\
2,3(1-7)\end{array}$ & $\begin{array}{l}2,47 \pm 1,53 \\
2,3(1-6,33)\end{array}$ & 0,320 \\
\hline Bütünleşme & $\begin{array}{c}2,03 \pm 1,40 \\
1,3(1-7)\end{array}$ & $\begin{array}{c}1,92 \pm 1,41 \\
1,3(1-7)\end{array}$ & 0,534 \\
\hline Kimlik Katma & $\begin{array}{c}2,33 \pm 1,59 \\
1,7(1-7)\end{array}$ & $\begin{array}{c}1,87 \pm 1,44 \\
1,0(1-7)\end{array}$ & 0,023 \\
\hline İçe Yansıtma & $\begin{array}{c}1,76 \pm 1,16 \\
1,0(1-7)\end{array}$ & $\begin{array}{c}1,68 \pm 1,18 \\
1,0(1-7)\end{array}$ & 0,599 \\
\hline Dışsal Düzenleme & $\begin{array}{c}2,21 \pm 1,60 \\
1,3(1-7)\end{array}$ & $\begin{array}{c}1,96 \pm 1,96 \\
1,0(1-7)\end{array}$ & 0,209 \\
\hline Motivasyonsuzluk & $\begin{array}{c}2,34 \pm 1,56 \\
1,7(1-7)\end{array}$ & $\begin{array}{l}1,97 \pm 1,97 \\
1,0(1-5,67)\end{array}$ & 0,076 \\
\hline
\end{tabular}

\#Mann Whitney U testi
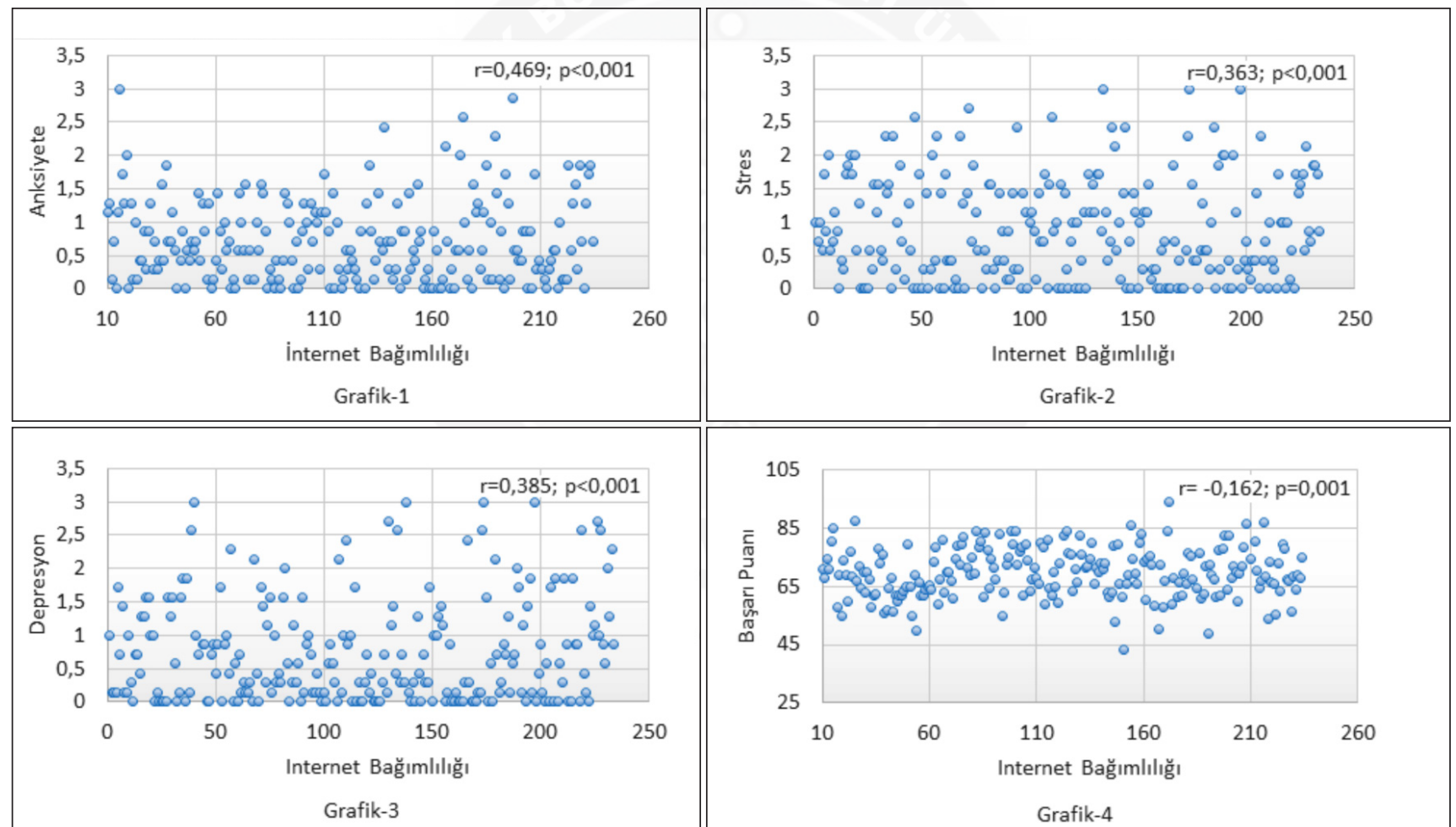

Şekil 1-4: Öğrencilerde internet bağımlılığının anksiyete, stres, depresyon ve başarı puanlarına etkileri.

\section{TARTIŞMA}

Bu çalışmada tıp fakültesi öğrencilerinde online oyun bağımlılı̆ının; anksiyete, stres, depresyon ve başarı arasındaki ilişki incelenmiş olup elde edilen sonuçlara göre, erkeklerle kadınlar arasında anksiyete, stres, depresyon ve internet bağımlılığı bakımından istatistiksel olarak anlamlı farklılık bulunmamıştır (Tablo 2). Öğrencilerin internet ba- ğımlıı̆̆ı puanları kadın ve erkek öğrenciler arasında farklılık göstermemekle beraber, öğrencilerin internet bağımlılığı puan ortalamalarına bakıldığında erkeklerin $29,9 \pm 9,3$ ve kadınların ise 30,6 \pm 8,5 bulunmuştur. Öğrencilerin alabileceği maksimum bağımlılık puanının 57 olduğu göz önüne alındığında aslında hem kadın hem erkek öğrencilerde orta derecede bir internet bağımlılığı varlığından söz edilebilir Pektaş ve Mayda (2018) yaptıkları çalışmada, çalışmaya 

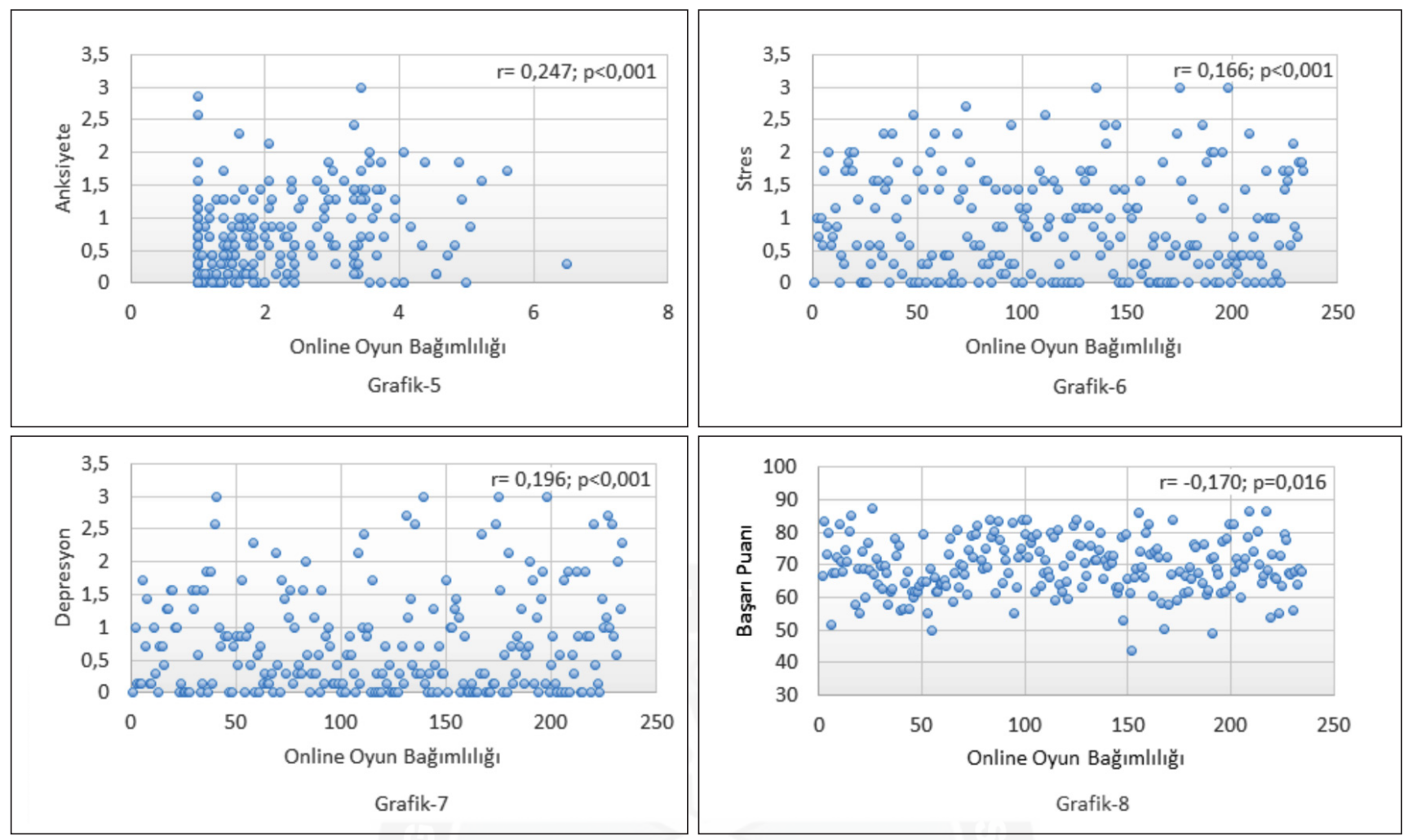

Şekil 5-8: Öğrencilerde online oyun bağımlılığının anksiyete, stres, depresyon ve başarı puanlarına etkileri.

alınan öğrencilerin \%56,9'unda internet bağımlılığının olduğu bulunmuş olup, bu çalışmadan farklı olarak erkek öğrencilerin internet bağımlılığının kadın öğrencilerden anlamlı derecede yüksek bulunmuştur (8). Durmuş ve ark. (2018) yaptıkları çalışmada da erkekle kadınlar arasında internet bağımlılığı bakımından istatistiksel olarak anlamlı farklılık bulunmuştur (9).

Oyun bağımlılığının ölçeğinin tüm alt boyutlarında erkek öğrencilerin puanları kadın öğrencilerden anlamlı derecede yüksek bulunduğundan erkek öğrencilerin oyun bağımlıIığına kadınlardan daha yatkın olduğu söylenebilir. Yavuz (2018) çalışmasında da erkek öğrencilerin kadın öğrencilerden anlamlı derecede daha yüksek bir oyun bağımlılığına sahip olduğunu bulmuştur (10).

Ancak öğrencilerin okuduğu döneme göre, stres, depresyon, internet bağımlılığı ve online oyun bağımlılıklarının değişmediği, sadece anksiyetenin dönemlere göre değiştiği görülmektedir (Tablo 4, 5). Literatürde yaşa göre söz konusu ölçeklerin değişkenlik gösterdiği gösterilmiş olsa da, dönem-1 ile dönem-3 arasında sadece 2 yaş ortalama fark olması yaşa göre olası bir değişkenliği bulamamamızın en önemli sebebi olmaktadır. Tablo 4 incelendiğinde öğrencilerin anksiyete düzeylerinin dönem-1'den dönem-3'e doğru gittikçe azaldığı görülmektedir. Dönem-1'de öğrencilerin anksiyetelerinin yüksek olmasında en temel sebebi olarak Tıp Fakültesi'ne yeni başlamış olmalarının getirdiği bir du- rum olduğunu düşünmekteyiz. Zaten söz konusu durum dönem geçtikçe azalma eğilimi göstermiştir. Benzer şekilde öğrencinin kiminle yaşadığı da, internet veya online oyun bağımlılığı ve anksiyete, stres, depresyon üzerinde bir etki göstermemektedir (Tablo 6, 7). Başpınar ve ark. (2016)'da tıpta uzmanlık öğrencisi hekimlerde yaptıkları çalışmada da kişilerin kiminle yaşadıklarına göre depresyon seviyelerinde anlamlı bir değişim bulunmamıştır (11).

Herhangi bir hobi alışkanlığı olanların depresyon puanlarının hobi alışkanlığı olmayanlardan anlamlı derecede düşük olduğu görülmektedir (Tablo 8). Herhangi bir boş zaman aktivitesi alışkanlığı olan birey hem daha düşük bir depresyon seviyesine sahip olmakta hem de internet ve online oyuna daha az zaman ayırmaktadır. Şekil 1-4 incelendiğinde, öğrencilerin internet bağımlığı arttıkça anksiyetelerinin, stres ve depresyon düzeylerinin arttığı, bununla beraber başarı puanlarının düştüğü görülmektedir. Benzer şekilde Şekil 5-8'i incelendiğinde, öğrencilerin online oyun bağımlığı arttıkça anksiyetelerinin stres ve depresyon düzeylerinin arttığı, yine başarı puanlarının internet bağımlılığında olduğu gibi azaldığı görülmektedir. Tablolarda elde edilen sonuçlara paralel olarak kişinin internet ve online oyun bağımlılığı arttıkça başarısı düşmekte; stres, anksiyete ve depresyon seviyeleri artış göstermektedir. Başarısı düşen öğrenci, daha fazla stres ve anksiyete yaşamakta, depresyon seviyesi artmakta ve kendini daha iyi hissetmek adına internet 
ve online oyunlara daha fazla yönelmekte, bu kısır döngüden çıkamayan öğrenci tam anlamıyla bağımlıığın etkisi altına girmektedir.

\section{Yazar Katkı Beyanı}

Veri toplama: Ezgi Hazal Kaymak, Fatma Nur Birgin, Gizem Tekeli, Hale Hatice Akgün, Hasan Bakla, Hatice Sümeyye Öncel, İstatistiksel analiz ve yorumlama: M. Çağatay Büyükuysal, Tablo ve Grafikler: M. Çağatay Büyükuysal, Makalenin yazımı: Ezgi Hazal Kaymak, Fatma Nur Birgin, Gizem Tekeli, Hale Hatice Akgün, Hasan Bakla, Hatice Sümeyye Öncel, M. Çağatay Büyükuysal, Yazının son düzenlemeleri: M. Çağatay Büyükuysal.

\section{Çıkar Çatışması}

Çıkar çatışması yoktur.

\section{Finansal Destek}

Finansal destek yoktur.

\section{Etik Kurul Onayı}

Zonguldak Bülent Ecevit Üniversitesi İnsan Araştırmaları Etik Kurulu'ndan 29.07.2020 tarihinde 853 protokol numarası ile izin alınmıştır.

\section{Hakemlik Süreci}

Kör hakemlik süreci sonrası yayınlanmaya uygun bulunmuş ve kabul edilmiştir.

\section{KAYNAKLAR}

1. Halk Sağlığı Genel Müdürlüğü. Bağımlılık nedir? (https:// sagligim.gov.tr/bagimlilik-liste/1067-bagimlilik-nedir.html Erişim: 17.01.2021)

2. Irmak AY, Erdoğan S. Ergen ve genç erişkinlerde dijital oyun bağımlıı̆ı̆: Güncel bir bakış. Türk Psikiyatri Dergisi 2016; 27(2):128-137.

3. Akın A, Çetin B. The depression anxiety and stress scale (DASS): The study of validity andreliability. Kuram ve Uygulamada Egitim Bilimleri 2007;7(1):260-268.

4. Yılmaz Ç, Boz H, Arslan A. Depresyon anksiyete stres ölçeğinin (DASS 21) Türkçe kısa formunun geçerlilik-güvenirlik çalışması. Finans Ekonomi ve Sosyal Araştırmalar Dergisi 2017; 2(2):78-91.

5. Şahin C, Korkmaz Ö. İnternet bağımlılığı ölçeğinin Türkçeye uyarlaması. Ahmed Keleşoğlu Eğitim Fakültesi Dergisi 2011;(32):101-115.

6. Can HC, Tozoğlu E. Üniversite öğrencilerinin internet bağımlıık düzeylerinin spor ve farklı değişkenler açısından incelenmesi. Spor Eğitim Dergisi 2019;3(3):102-118.

7. Akın A, Kaya Ç, Demirci İ. Oyun motivasyonu ölçeğinin geçerliği ve güvenirliği. Mersin Üniversitesi Eğitim Fakültesi Dergisi 2015;11(1):18-31.

8. Pektaş I, Mayda AS. Tıp fakültesi öğrencilerinde internet bağımlılığı düzeyi ve etkileyen etmenler. Sakarya Tıp Dergisi 2018;8(1):52-62.

9. Durmuş H, Günay $O$, Yıldız S, Timur A, Balcı E. Üniversite öğrencilerinde internet bağımlılığı ve üniversite yaşamı boyunca değişimi. Anadolu Psikiyatri Dergisi 2018;19(4):383389.

10. Yavuz O. Özel yetenekli öğrencilerde internet ve oyun bağımlıı̆̆ ile algılanan sosyal destek düzeylerinin incelenmesi. Yaşam Becerileri Psikoloji Dergisi 2018;2(4):281-296.

11. Başpınar R, Cihan FG, Kutlu R. Tıpta uzmanlık öğrencisi hekimlerde depresyon sıklığı ve etkileyen faktörlerin değerlendirilmesi. Mustafa Kemal Üniversitesi Tıp Dergisi 2016;7(25):1-9. 


\section{EKLER}

Ek-1 Çalışmada kullanılan anket formu örneği
1) Cinsiyetiniz? ( )Erkek
( ) Kadın
2) Kaç yaşındasınız?
3) 2018-2019 Eğitim Öğretim yılında eğitim gördüğünüz sınıfı işaretleyiniz?
( ) Dönem 1
( ) Dönem 2
( ) Dönem 3
4) Konaklama durumunuzu işaretleyiniz?
( ) Ailesiyle
( ) Ev veya apartta tek
( ) Ev veya apartta arkadaşlarılyla
( ) Devlet yurdunda
( ) Özel yurtta tek
( ) Özel yurtta arkadaşlarılyla
5) Annenizin mesleğini işaretleyiniz?
( )Çalışmıyor
( )Memur
()Akademisyen
( )Özel sektörde çalışan
( )Özel sektörde işveren ()Esnaf
( )Emekli
6) Babanızın mesleğini işaretleyiniz?
( )Çalışmıyor
( )Memur
()Akademisyen
( )Özel sektörde çalışan
( )Özel sektörde işveren ( )Esnaf
( )Emekli
7) Aylık gelir durumunuzu işaretleyiniz (öğrencinin)?
( ) 0-500 ( ) 501-1000
( ) 1001-1500
( ) 1501-2000
( ) $2001+$
8) Aylık harcadığııız para miktarını işaretleyiniz?
( ) 0-500 ( ) 501-1000
() $1001-1500$
( ) $1501-2000$
( ) $2001+$

9) Harcadığııız miktarın yüzde kaçını online oyun için harcıyorsunuz?
( ) $\% 0-\% 10$
( ) $\% 11-\% 20$
( ) $\% 21-\% 40$
( ) $\% 41-\% 60$

10) Beslenme alışkanlığınız nasııdır?

( ) Öğün atlamam.

( ) Çoğu zaman kahvaltı yapmadan çıkarım.

( ) Öğlen ve akşam öğünlerinde atıştırmalık bir şeyler tüketirim.

( ) Bilgisayar, tablet, telefon vb. araçlar karşısında yiyorum fakat ögün atlamam.

( ) Bilgisayar, tablet, telefon vb. araçlar karşısında yiyorum ögünlerim düzensiz.

11) Uyku düzeniniz nasıl?

( ) Geceleri oyun/dizi karşısında vakit geçirir, geç yatarım.

( ) Geceleri uyumam, gündüz uyurum.

( ) Geceleri yatar, sabah kalkarım.

12) Hobiniz ve/veya hobileriniz var mı? ( ) Var ( ) Yok

Varsa Belirtiniz

13) Girmiş olduğunuz kurul sınavlarının notu yazınız.

$\begin{array}{llllll}\text { Kurul-1 Kurul-2 } & \text { Kurul-3 } & \text { Kurul-4 Kurul-5 } & \text { Kurul-6 } & \text { Kurul-7 }\end{array}$

Puan: 
Kaymak EH ve ark.

\section{Ek-2 Depresyon Anksiyete ve Stres Ölçeği (DASS)}

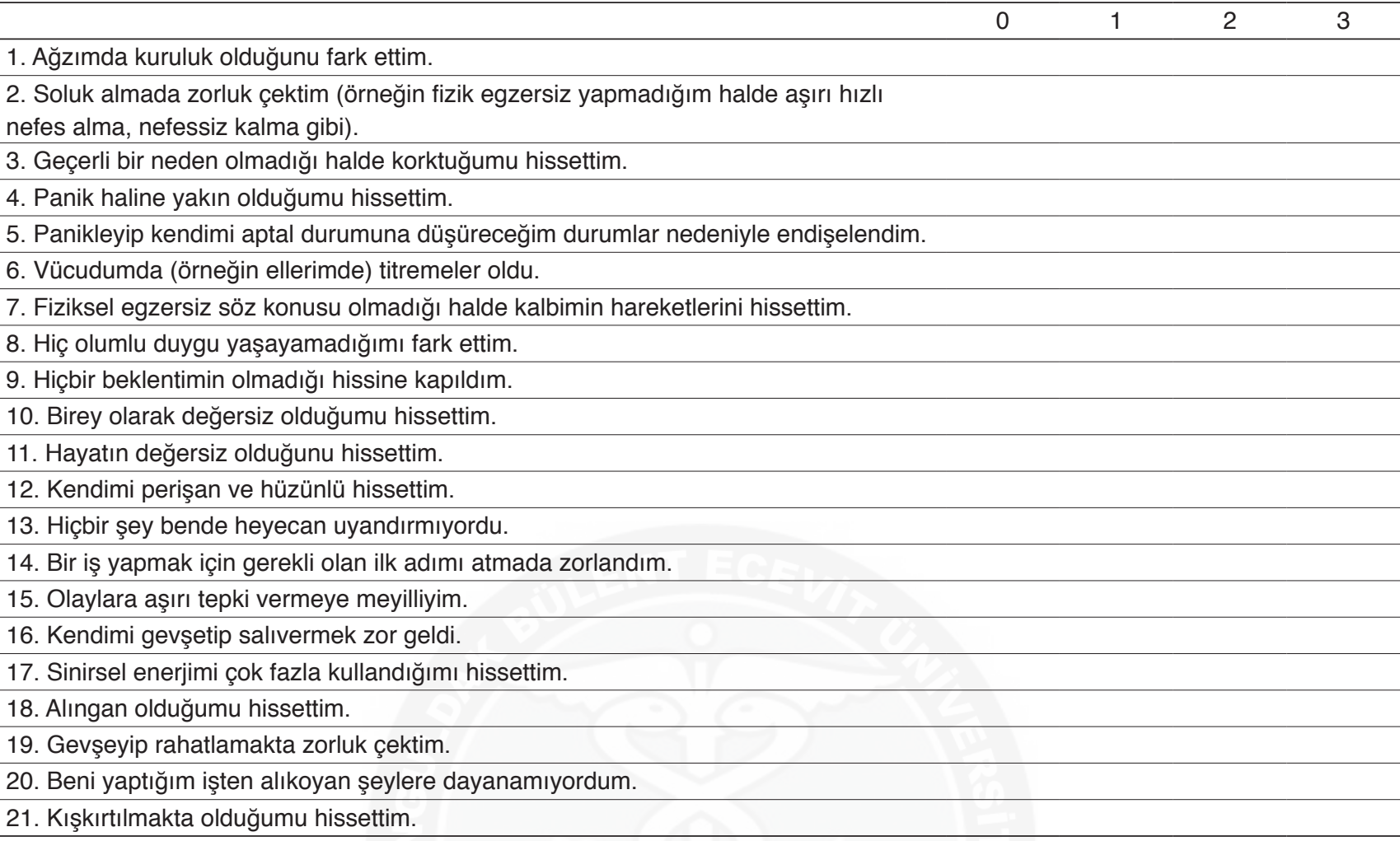

\section{Ek 3 İnternet Bağımlılığı Ölçeği}

1. İnternete uzun süreli bağlanmadığımda aklım internetle meşguldür.

2. İnternete bağlı olup online olmadığımda aklım sürekli olarak internete takılıp kalıyor.

3. Çok uzun süre internetten uzak kalmışsam, huzursuz ve sinirli oluyorum.

4. İnternette önceden planladığımdan daha çok zaman harcıyorum.

5. İnternette birkaç dakikalığına sörf yapmayı girip, bir türlü bırakamıyorum.

6. İnternette geçirdiğim zamanı azaltmayı denedim ama sonuç alamadım.

7. İnternet için harcayabileceğim paradan çok daha fazlasını harcıyorum.

8. İnternette geçirdiğim zaman, başlangıçtaki dönemle karşılaştırılınca gitgide artıyor.

9. İnternete daha fazla zaman ayırma isteğim, geçmişe göre sürekli artıyor.

10. Başlangıçta sadece yapmam gereken işler için online etkinliklere vakit ayırırken, şimdi internete daha

fazla zaman ayırıyorum.

11. İnternet etkinlikleri günlük yaşamımı giderek daha fazla yönlendiriyor.

12. İnternet kullanmaya başladığımdan beri, bazı arkadaşlarım benden uzaklaştı.

13. Çok değer verdiğim kişiler, internette çok fazla zaman harcadığımdan benden şikâyetçi oluyorlar.

14. Okul/meslek/aile ve benzeri yaşamımdaki verimliliğim internet kullanmam yüzünden azalıyor.

15. Çok değer verdiğim kişiler bende, internet kullanmaya başladığımdan beri olumsuz yönde değişiklikler olduğunu söylüyorlar.

16. İnternette daha fazla zaman geçirebilmek için sık sık sorumluluklarımı aksatıyorum.

17. İnternet yüzünden bazen randevularımı kaçırıyorum.

18. Online dünyasını keşfettiğim andan itibaren başkalarıyla daha az zaman geçiriyorum.

19. İnternetle öylesine sık ve yoğun meşgul oluyorum ki bazen işverenlerimle /okulla /aile bireyleri ve benzeri ile sorunlarım oluyor.

1:katılıyorum; 2:kararsızım; 3:katılmıyotum 


\section{Ek 4 Oyun Motivasyonu Ölçeği}

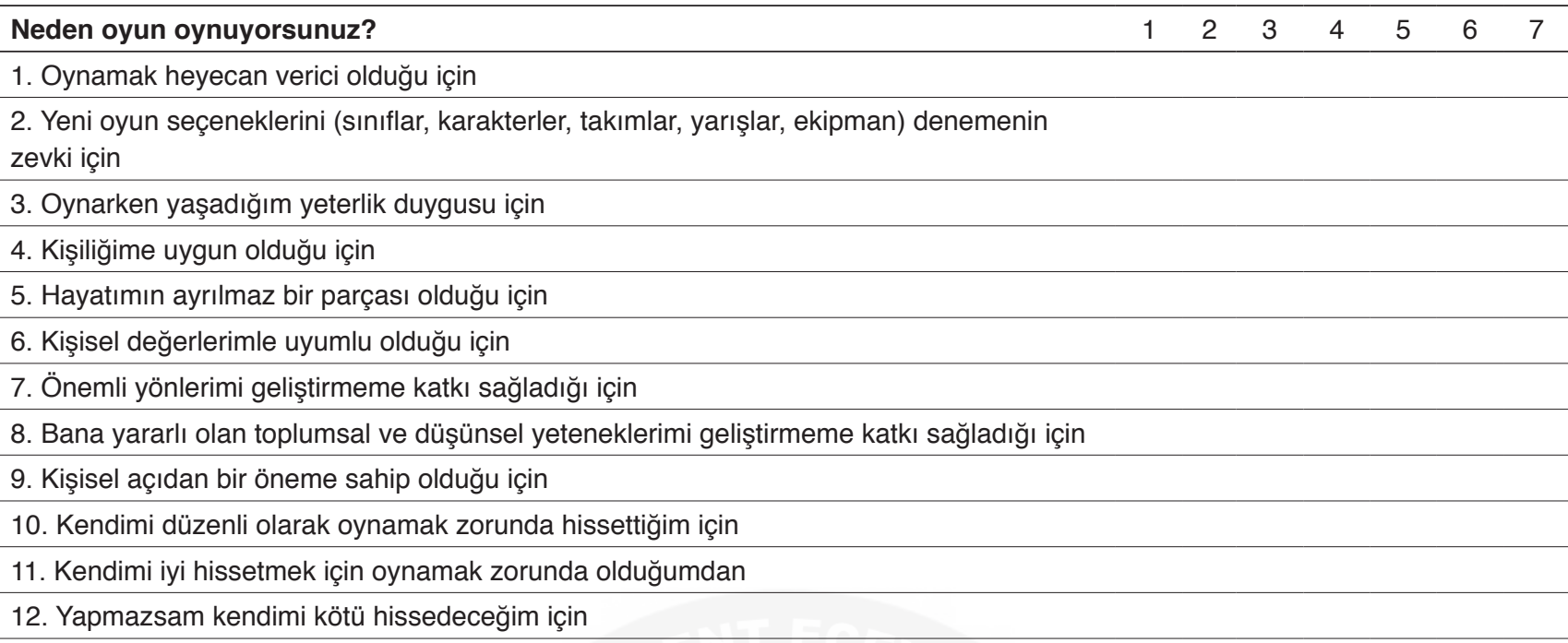

13. Güçlü ve az bulunan eşyalar (zırh, silah) ve sanal para birimleri (altın parçaları, mücevherler) elde etmek için, ya da oyunun gizli/kısıtlanmış öğelerini (yeni karakterler ekipman, haritalar) açmak için

14. İyi bir oyuncu olmanın saygınlığı için

15. Oyun içi ödül ve kupaları kazanmak veya karakter/avatarların seviyelerini ve deneyim puanlarını arttırmak için

16. Benim için artık açık değil; bazen bunun benim için iyi olup olmadığını kendime soruyorum

17. Önceleri iyi nedenlerim vardı; ama şimdi devam edip etmeyeceğimi kendime soruyorum

18. Dürüst olmak gerekirse, bilmiyorum; zamanımı boşa harcadığımı düşünüyorum.

1: Hiç Katılmıyorum; 7: Tamamen Katılıyorum 